$8 \quad{ }^{1}$ Programa de Biologia Celular e do Desenvolvimento, Instituto de Ciências

9 Biomédicas, ${ }^{2}$ Faculdade de Farmácia, ${ }^{3}$ Instituto de Biofísica Carlos Chagas Filho,

10 Universidade Federal do Rio de Janeiro, Rio de Janeiro, RJ, Brazil.

11

12 Keywords: Diagnostic, screening, laboratory mice, pathogen-free, infection.

\section{PCR-based detection of Helicobacter spp. in mice from different animal houses in Rio de Janeiro, Brazil}

\author{
Gabriel E. Matos-Rodrigues ${ }^{1}$, Carolinne C. Masseron ${ }^{1}$, Fabio J. Moreira da Silva ${ }^{1}$, \\ Marcel Flajblat ${ }^{3}$, Lilian O. Moreira ${ }^{2} *$, Rodrigo A. P. Martins ${ }^{1 *}$
}

Running title: Detection and screening of Helicobacter spp. in mice

*Corresponding authors: Rodrigo A. P. MARTINS: Instituto de Ciências Biomédicas, Universidade Federal do Rio de Janeiro (UFRJ), Laboratório Compartilhado 2, Bloco F, Sala F1-08, Centro de Ciências de Saúde (CCS), Cidade Universitária, 21941-902, Rio de Janeiro, RJ, Brazil. Phone: +55 21 39386467. Email: rodrigo.martins@icb.ufrj.br and Lilian de Oliveira MOREIRA, Laboratório de Bacteriologia e Imunologia Clínica, Rua Professor Paulo Rocco, CCS, Bloco A2-07, Cidade Universitária, 21941-617, Rio de Janeiro, RJ, Brazil. E-mail: lilian@pharma.ufrj.br 


\section{Abstract}

2

Pathogenic microbial detection and control in breeding and experimental

3 laboratory animal facilities is essential to guarantee animal welfare, data validity and

4 reproducibility. Helicobacter spp. is known to severely affect mice health, mainly in

5 immunocompromised strains, what may affect experimental outcomes. This study

6 aimed to screen for Helicobacter spp. in mice from four different animal houses in Rio

7 de Janeiro, Brazil using a PCR for 16 S ribosomal RNA. A pair of primers was designed

8 to specifically identify Helicobacter species that commonly infect laboratory mice.

9 Following PCR reaction, the expected 375 base pairs (bp) amplification product was

10 purified, sequenced and showed a 95\% similarity when compared to deposited

11 sequences of Helicobacter hepaticus and Helicobacter bilis. Then, the presence of

12 Helicobacter spp. in both feces and intestines samples was analyzed. Helicobacter spp

13 DNA was detected in $59.6 \%$ of the fecal and $70.17 \%$ of the intestine samples. Although

14 Helicobacter spp screening is recommended by institutional animal health monitoring

15 programs worldwide it is still not mandatory by Brazilian animal welfare regulation.

16 Our study, the first to monitor Helicobacter species in laboratory mice in Brazil,

17 demonstrates the possibility of using a low cost, rapid molecular diagnostic test to

18 screen Helicobacter and highlights the importance of regular microbiological

19 verification of mice used for research in Brazilian animal houses. 
1

3

4

5

6

\section{Introduction}

The use of rodents as experimental models in basic and pre-clinical research has been essential for scientific progress. Reproducible research requires the use of laboratory animals free of diseases and other conditions that could interfere with experimental outcome. Infections that naturally occur in mice, even when subclinical, may influence animal's physiology, immunity and behavior. For this reason, even in the absence of clinical signs, experimental rodents may become inadequate for research due to the presence of microorganisms, like bacteria, viruses or protozoa (Baker et al. 1998; Nicklas et al. 1999; Whary and Fox 2006; Besselsen et al. 2008, Pritchett-Corning et al. 2009). Moreover, immunosuppressed mice are prone to exhibit clinical manifestations from natural infections (Whary and Fox, 2006; Chichlowski and Hale, 2009). Therefore, the establishment of animal health status monitoring routines and quality control of laboratory mice maintained in facilities is indispensable (FELASA, 2014).

Helicobacter bacteria are among the microorganisms that infect laboratory rodents (Pritchett-Corning et al. 2009). Helicobacter spp. colonizes primarily rodents' cecum and colon, but also stomach, gallbladder and liver. These microorganisms are shaded in feces leading to horizontal transmission through fecal-oral contact (Whary and Fox, 2006). Previous studies reported that, in mice, Helicobacter spp. infection is associated gastrointestinal and inflammatory bowel diseases as well as breast, liver, gastric and colon cancers (Chichlowski and Hale 2009) and that it can also affect mice reproduction (Sharp et al. 2008; Chichlowski and Hale 2009). In addition, immunodeficient animals are more susceptible to Helicobacter infection. In these mice, infection by H. hepaticus, H. bilis, H. muridarum H. rappini may lead to intestine manifestations, such as thyphlocolitis, hepatitis, gastritis and cancer (Whary et al. 2006; Mähler and Nicklas, 2012). 
1

2 (Taylor et al. 2007; Wasimuddin et al. 2012) and were previously detected in wild

Helicobacter spp. are highly prevalent bacteria in animal facilities worldwide rodents in Brazil (Comunian et al., 2006). To our knowledge, the prevalence of Helicobacter infection in laboratory rodents in Brazil has never been studied. The present study aimed to detect Helicobacter spp. bacteria in rodents of animal houses localized at Universidade Federal do Rio de Janeiro, Brazil using a PCR-based diagnostic test.

\section{Materials and methods}

\section{Mice}

The mouse strains were obtained from four different animal houses (AH-A-AH-D) localized at Universidade Federal do Rio de Janeiro, Brazil. Mice of mixed genetic background $(n=57)$ between 15 and 22 weeks of age (mean age, 19 weeks) were randomly selected. All animals were housed conventionally, fed a standard diet and water ad libitum, and euthanized by exposure to $\mathrm{CO}_{2}$ prior to intestine (cecum and/or colon) collection. Recovered feces ( 1 fecal pellet per animal) and intestine sections were frozen in liquid nitrogen and maintained at $-80^{\circ} \mathrm{C}$. All mice were treated according to the protocol (No. 092/15) approved by the Animal Ethics Committee of UFRJ.

\section{DNA extraction}

DNA extraction of fecal samples (about $1 \mathrm{~cm}$ pellet, 50-80 mg) (Beckwith et al., 1997) or lower bowel (about $1 \mathrm{~cm}$ of cecum or colon) was performed using two different methods. In method one, samples were incubated in $100 \mu \mathrm{L}$ of $25 \mathrm{mM} \mathrm{NaOH}$ (Isofar, 1326) for $1 \mathrm{~h}$ at $98^{\circ} \mathrm{C}$. Then, $400 \mu \mathrm{L}$ of $10 \mathrm{mM} \mathrm{pH} 7.4$ Tris buffer (Sigma, T1503) was added and the samples were stored at $-20^{\circ} \mathrm{C}$. In method two, samples were incubated in 
$1200 \mu \mathrm{L}$ proteinase $\mathrm{K} 1 \mathrm{mg} / \mathrm{mL}$ (Sigma, P2308) for $16 \mathrm{~h}$ at $50^{\circ} \mathrm{C}$ and then mixed with

$2160 \mu \mathrm{L}$ of saturated $\mathrm{NaCl}$ (Isofar, 310) following centrifugation at $19.000 \mathrm{~g}$ for $15 \mathrm{~min}$.

3 Then $300 \mu \mathrm{L}$ of the supernatant were collected, mixed with $1 \mathrm{~mL}$ of cold ethanol (Merck,

4 100983), and centrifuged at $19.000 \mathrm{~g}$ for $15 \mathrm{~min}$. DNA pellets were ressuspended in

$5200 \mu \mathrm{L}$ of TE buffer (Tris $10 \mathrm{mM}$-EDTA $1 \mathrm{mM}, \mathrm{pH} 7.6$ ) and stored at $-20^{\circ} \mathrm{C}$.

\section{Polymerase chain reaction}

Previously described primer sequences that recognize a conserved region of the $16 \mathrm{~S}$ ribosomal RNA gene (16S rRNA) and specifically detect four Helicobacter species $(H$. hepaticus, H. bilis, H. muridarum and H. rappini) were used (Proietti et al. 2009; BuryMoné et al. 2003; Beckwith 1997; Riley et al. 1996). The reaction mixture (final volume $20 \mu \mathrm{L}$ ) contained $0.5 \mu \mathrm{M}$ of each primer (H276f: 5'-CTATGACGGGTATCCGGC-3' and H676r: 5'-ATTCCACCTACCTCTCCCA-3'), 5x Green GoTaq ${ }^{\circledR}$ Flexi Buffer

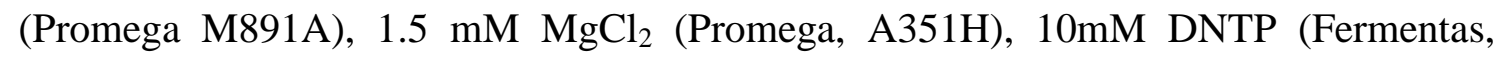
R0199) and $0.025 \mathrm{U}$ of Hotstart Taq polymerase (Promega) and different amounts of DNA (from $0.01 \mathrm{ng}$ to $100 \mathrm{ng}$ ). The amplification conditions used were $94^{\circ} \mathrm{C}$ for $5^{\prime}$ followed by 35 cycles of $2^{\prime}$ at $94^{\circ} \mathrm{C}, 2^{\prime}$ at $53^{\circ} \mathrm{C}$ and $30^{\prime \prime}$ at $72^{\circ} \mathrm{C}$ for $5^{\prime}$ at $72^{\circ} \mathrm{C}$. The PCR product was analyzed by electrophoresis in 1\% agarose gel (Sigma, A9539).

\section{DNA sequencing}

The 375 bp PCR amplicon was purified (GE Healthcare Illustra GFX PCR DNA and Gel Band Purification kit (GE, 28903470) according to the manufacturer's instructions. A $7 \mu \mathrm{L}$ of the reaction mixture, containing 50ng of DNA template and 3.2 pmol of primer (5'-CTATGACGGGTATCCGGC-3') was submitted to an ABI 3130x1 automated sequencer. Obtained sequence was compared to H. hepaticus, H. bilis, $H$. 
1

2

3

\section{$4 \quad$ Results}

\section{$5 \quad$ PCR assay and amplicon sequencing} (https://blast.ncbi.nlm.nih.gov). Helicobacter species.

muridarum, Mus musculus and Escherichia coli genomes using the Blast platform

To investigate the presence of Helicobacter spp, we performed PCR assays using primers previously designed to recognize a conserved region of the $16 \mathrm{~S}$ rRNA gene, specific for the Helicobacter genus (Riley et al. 1996; Proietti et al. 2009; BuryMoné et al. 2003; Beckwith, et al., 1997). Primer-BLAST tool was used to confirm primers annealing against three different genomes: (i) H. hepaticus (GI: 32263428), (Riley et al., 1996), (ii) Mus musculus (GI: 372099100), to search to nonspecific amplifiable targets and (iii) to E. coli (GI: 26111730), considering the possibly of nonspecific annealing with DNA from a bacteria commonly found in feces. Primer-BLAST search confirmed that the selected primers specifically recognize a conserved region of the H. hepaticus genome, indicating that it would also anneal to the DNA of other

Since feces may contain substances that can inhibit the PCR and lead to false negative results (Monteiro et al. 1997), we first tested $\mathrm{NaOH}$ extracted DNA from the feces of a mouse naturally infected with Helicobacter spp (kindly provided by Dr. Rovilson Gilioli, CEMIB, Unicamp). A serial dilution (0.1, 1, 10, and 100ng) of this Helicobacter spp.-containing DNA was performed and, as expected from the bioinformatics analysis, only the expected amplicon of $375 \mathrm{bp}$ was detected in the three higher DNA concentrations tested (Figure 1). The successful amplification using 1 or 10 ng of DNA indicated a reasonable sensitivity of this reaction. To evaluate primers 
1 specificity to Helicobacter species, we isolated E. coli bacteria and extracted its DNA

2 using two different methods ( $\mathrm{NaOH}$ or proteinase $\mathrm{K}$ ). Following PCR, no amplification

3 was observed with the input of 1, 10 or 100 ng of E. coli DNA (Figure 2).

To determine whether the obtained PCR 375bp amplicon would correlate to the region of the Helicobacter genome, two samples were amplified, the PCR products were purified, sequenced and compared to the 16S rRNA gene sequences of $H$. hepaticus (GI:32265499), H. bilis (GI:806984271) and H. muridarum (GI:219846348) using BLAST platform. A $~ 95 \%$ similarity between the sequence of our amplicons and those deposited in NCBI database further validated the specificity of the PCR assay.

\section{PCR-based detection of Helicobacter spp. in mice}

In order to evaluate the presence of Helicobacter spp. in mouse samples, first we collected feces or intestine DNA samples from 57 randomly selected mice from four different animal houses. Then, we performed PCR analysis to analyze the presence of Helicobacter spp DNA in these samples (Figure 3). We found that $59.6 \%$ of the feces samples were positive, while $70.17 \%$ (40 of 57) of the intestine samples contained detectable Helicobacter spp DNA (Table 1). It is important to point that not all animals were tested for both feces and intestines due to sampling limitations. According to the PCR-based diagnostic tests of the feces, the occurrence of Helicobacter spp. infection in the different animal houses $(\mathrm{AH})$ ranged from $84 \%$ (AH-C) to $14 \%$ (AH-D). The analysis of intestine samples revealed a proportion of Helicobacter spp.-infected mice ranging from $90 \%(\mathrm{AH}-\mathrm{B})$ to $55 \%(\mathrm{AH}-\mathrm{D})$. 
1

\section{Discussion}

The use of living animal models in research requires periodic sanitary screening of animals due to the possibility of undesired infection, which may compromise animal welfare and scientific research. For this reason, laboratory mice should be periodically monitored for parasite, bacteria, fungi and virus, using different methods such as culture, microscopy, PCR and serology (Mähler et al., 2014; FELASA, 2014).

PCR is accepted as one of the most reliable methods for Helicobacter spp. detection (Chichlowski and Hale 2009; Casagrande et al, 2010), since culturing these microorganisms requires dedicated infrastructure, laborious and fastidious procedures and also because the presence of several Helicobacter species colonizing mice intestine may interfere with bacterial identification (Shames et al. 1995). In addition, serological tests for Helicobacter spp. detection present low specificity and may generate false positive results (Whary et al. 2000; Whary and Fox, 2006; Chichlowski and Hale 2009).

Here, we used primers against $16 \mathrm{~S}$ rRNA able to identify three different Helicobacter species that may be associated with several infection processes in susceptible mice strains (Riley et al. 1996). In attention to cross-reactivity issues that could lead to the detection of related microorganisms, first primers sequences were compared to sequence databases from various Helicobacter species and then PCR products were sequenced and compared with published sequences of $M$. musculus and E. coli. Bioinformatics analysis confirmed that the pair of primers used annealed specifically to conserved sequences of the 16S rRNA gene of Helicobacter bacteria.

PCR sensitivity was determined by serial dilutions of DNA extracted from feces and/or intestine. For DNA extraction, we used $\mathrm{NaOH}$ or proteinase $\mathrm{K}$ instead of commercial extraction kits. Both methods elicited good quality DNA and may work as 
1 alternative and less expensive method of DNA extraction for PCR-based screening tests

2 of intestine and feces. PCR product amplification in the expected size was observed

3 using 1 and 10ng of DNA mass. DNA sequence analysis confirmed a similarity of

$4 \quad$ 95\% with the $16 \mathrm{~S}$ rRNA gene of $H$. hepaticus, $H$. bilis and $H$. muridarum. The

5 screening for bacterial species of the same genus using a single pair of primers is

6 advantageous since it's minimizes time and costs of the assay (Battles et al. 1995;

7 Shames et al. 1995). It's important to point out that other Helicobacter species have

8 been associated with rodent infection (Hodzic et al. 2001; Fox et al. 2010), therefore

9 depending on the established goals of each animal facility, the choice of primers and PCR strategy for diagnosis may be more challenging. In addition, in some cases the investigation for individual bacterial species identification may be of interest. Importantly, a high prevalence of Helicobacter spp.-infected mice was observed in the facilities screened in this study. Because the prevalence of Helicobacter spp. in rodents used for research in Brazil remains largely unknown, the development and application of non-expensive, relatively simple diagnostic tests to routinely screen mice colonies kept in Brazilian research facilities are particularly useful. The successful use of feces is interesting, because it avoids euthanasia, being a useful tool to monitor contamination of small mice colonies. Notably, international councils, such as FELASA and the AALAS, recommend the use of sentinels animals for the health screening routine of rodent colonies (Lipman and Homberger, 2003, FELASA, 2014), while the Brazilian National Council of Animal Experimentation Control (CONCEA) (CONCEA, 2016) does not. Taken into consideration that in Brazil, few companies provide services of microbiological screening tests for laboratory rodents, our findings highlight the need for the development of accessible monitoring routines in order to prevent use of infected animals. 
1 Figure legends:

2 Figure 1: Sensitivity of the PCR-based assay for Helicobacter spp. detection: DNA

3 extracted from feces of a mouse that was previously diagnosed with Helicobacter

4 infection was used as the input of the PCR. Labels: Ld = 100 bp DNA ladder; $1=100$

$5 \mathrm{ng} ; 2=10 \mathrm{ng} ; 3=1 \mathrm{ng}$ and $4=0.1 \mathrm{ng}$ and $(-)=$ no DNA; $1 \%$ agarose gel.

6 Figure 2: Specificity of the PCR-based assay for Helicobacter spp. detection: DNA

7 extracted from E. coli bacteria (1-8) and DNA extracted from feces of a mouse that was

8 previously diagnosed with Helicobacter infection (+) were used as the input of the PCR.

9 Labels: Ld $=100$ bp DNA ladder; 1-4: respectively, 100, 10, 1 or $0.1 \mathrm{ng}$ of E. coli

10 extracted with $\mathrm{NaOH}$ protocol; 5-8: respectively, 100, 101 or 0.1 ng of E. coli

11 extracted with proteinase K protocol; (+) $100 \mathrm{ng}$ of Helicobacter spp. DNA positive

12 control; $1 \%$ agarose gel.

Figure 3: PCR-based detection of Helicobacter spp in feces and/or intestine of mice: Randomly selected representative samples of DNA extracted from mice feces (A) or intestines (B). (A) Labels: (+) Helicobacter spp. DNA positive control; 1-12 = DNA extracted from mice feces; (B) Labels: (+) Helicobacter spp. DNA positive control; 1$12=$ DNA extracted from mice intestine; $1 \%$ agarose gel.

\section{Acknowledgements}

We thank Severino Gomes for technical assistance. The laboratory where this work was performed was supported by grants from the Conselho Nacional de Desenvolvimento Científico e Tecnológico (CNPq), FAPERJ and International Retinal Research Foundation (IRRF) to R.A.P.M. 


\section{References}

2 Baker, DG. Natural pathogens of laboratory mice, rats, and rabbits and their effects on

3 research. Clin Microbiol Rev, 11 (2): 231-266. 1998.

4 Battles JK, Williamson JC, Pike KM, Gorelick PL, Ward JM, Gonda MA. Diagnostic

5 assay for Helicobacter hepaticus based on nucleotide sequence of its 16S rRNA gene. J.

6 Clin Microbiol, 33: 1344-1347. 1995.

7 Beckwith CS, Franklin CL, Hook RR Jr, Besch-Williford CL, Riley LK. Fecal PCR 8 assay for diagnosis of Helicobacter infection in laboratory rodents. J Clin Microbiol, 35

9 (6): 1620-1623. 1997.

Besselsen DG, Franklin CL, Livingston RS, Riley LK. Lurking in the shadows: emerging rodent infectious diseases. ILAR J, 49(3): 277290. 2008.

Comunian LB, Moura SB, Paglia AP, Nicoli JR, Guerra JB, Rocha GA, Queiroz DM. Detection of Helicobacter species in the gastrointestinal tract of wild rodents from Brazil.Curr Microbiol. 53(5): 370-373, 2006.

Conselho Nacional de Controle de Experimentação Animal (CONCEA).,2016. http://www.mctic.gov.br/mctic/opencms/institucional/concea/paginas/guia.html

Chichlowski M, Hale LP. Effects of Helicobacter infection on research: the case for eradication of Helicobacter from rodent research colonies. Comp Med, 59(1): 10-17, 2009.

Federation of European Laboratory Animal Science Associations (FELASA). FELASA recommendations for the health monitoring of mouse, rat, hamster, guinea pig and rabbit colonies in breeding and experimental units. Lab Animals, 48(3): 178-192. 2014. 
1 Fox JG, Ge Z, Whary MT, Erdman SE, Horwitz BH. Helicobacter hepaticus infection

2 in mice: models for understanding lower bowel inflammation and cancer. Mucosal

3 Immunol, 4: 22-30. 2010.

4 Hodzic E, McKisic M, Feng S, Barthold SW. Evaluation of diagnostic methods for

$5 \quad$ Helicobacter bilis Infection in laboratory mice. Comp Med, 51(55) 406-412 . 2001.

6 Lipman NS, Homberger FR. Rodent quality assurance testing: use of sentinel animal 7 systems. Lab Anim, 32:36-43. 2003.

8

Mähler M, W Nicklas. Health management and monitoring. The Lab Mouse, 601-620. 2012.

Monteiro L, Bonnemaison D, Vekris A, Petry KG, Bonnet J, Vidal R, Cabrita J, Mégraud F. Complex polysacharides as PCR inhibitors in feces: Helicobacter pylori model. J Clin Microbiol, 35(4): 995-998. 1997.

Nicklas W, Hornberger FR, IIIgen-Wilcke B. Jacobi K, Kraft V. Mahler I KM, Meyer H, Pohlmeyer-Esch G. Report of the working group on hygiene of the gesellschaft fur Versuchstierkunde - Society for Laboratory Animal Science (GV-SOLAS) Implications of infectious agents on results of animal experiments. Lab Anim, 33(1): 39-87. 1999.

Pritchett-Corning KR, Cosentino J, Clifford CB. Contemporary prevalence of infectious agents in laboratory mice and rats. Lab Anim, 43: 165-173. 2009.
Casagrande PP, Bietta
A, Brachelente
C, Lepri
E, Davidson I, Franciosini MP.

Detection of Helicobacter spp. in gastric, fecal and saliva samples from swine affected by gastric ulceration. J Vet Sci, 11(3): 221-225. 2010. 
1 Riley LK, Franklin CL, Hook RR Jr, Besch-Williford C Identification of Murine

2 Helicobacters by PCR and Restriction Enzyme Analyses. J Clin Microbiol, 34 (4): 942-

$3 \quad 946.1996$.

4 Shames B, Fox JG, Dewhirst F, Yan L, Shen Z, Taylor NS. Identification of widespread

5 Helicobacter hepaticus infection in feces in commercial mouse colonies by culture and

$6 \quad$ PCR assay. J Clin Microbiol, 33(11): 2968-2972. 1995.

7 Sharp JM, Vanderford DA, Chichlowski M, Myles MH, Hale LP. Helicobacter

8 infection decreases reproductive performance of IL10-deficient mice. Comp Med. $9 \quad$ 58(5):447-453. 2008.

Taylor NS, Xu S, Nambiar P, Dewhirst FE, Fox JG. Enterohepatic Helicobacter species are prevalent in mice from commercial and academic institutions in Asia, Europe, and North America. J Clin Microbiol, 45(7): 2166-2172. 2007.

Wasimuddin, Č́̌žková D, Bryja J, Albrechtová J, Hauffe HC, Piálek J. High prevalence and species diversity of Helicobacter spp. detected in wild house mice. App Environ Microbiol, 78(22): 8158-8160. 2012.

Whary MT, Cline JH, King AE, Hewes KM, Chojnacky D, Salvarrey A and Fox JG. Monitoring sentinel mice for Helicobacter hepaticus, $H$. rodentium, and $H$. bilis infection by use of polymerase chain reaction analysis and serologic testing. Comp Med; 50(4):436-43. 2000.

Whary MT, Fox JG. Detection, eradication, and research implications of Helicobacter infections in laboratory rodents. Lab Animal, 35 (7): 25-27. 2006. 
Table 1: Prevalence of Helicobacter spp. infected mice as determined by Helicobacter genus-specific PCR analysis.

\begin{tabular}{|c|c|c|c|}
\hline \multirow[t]{2}{*}{$\begin{array}{l}\text { Animal } \\
\text { mouse }\end{array}$} & \multirow[t]{2}{*}{$\begin{array}{l}\text { Mouse } \\
\text { strain }\end{array}$} & \multicolumn{2}{|c|}{$\begin{array}{l}\mathbf{N}^{\mathbf{0}} \text {. of mice positive / total number of mice tested } \\
\text { (\% of positive PCR) }\end{array}$} \\
\hline & & Feces & Intestine \\
\hline \multirow[t]{2}{*}{$\mathbf{A}$} & C57BL/6 & $13 / 22$ & $15 / 25$ \\
\hline & & $(59 \%)$ & $(60 \%)$ \\
\hline \multirow[t]{2}{*}{$\mathbf{B}$} & C57BL/6 & $3 / 5$ & $9 / 10$ \\
\hline & & $(60 \%)$ & $(90 \%)$ \\
\hline \multirow[t]{2}{*}{$\mathbf{C}$} & $\mathrm{BALB} / \mathrm{c}$ & $11 / 13$ & $11 / 13$ \\
\hline & & $(84 \%)$ & $(84.6 \%)$ \\
\hline \multirow[t]{2}{*}{ D } & C57BL/6 & $1 / 7$ & $5 / 9$ \\
\hline & & $(14 \%)$ & $(55.6 \%)$ \\
\hline Total & & $28 / 47$ & $40 / 57$ \\
\hline
\end{tabular}


$\begin{array}{llllll}\text { Ld } & 1 & 2 & 3 & 4 & -\end{array}$ 
Matos-Rodrigues et al. Figure 2

$\begin{array}{llllllllll}1 & 2 & 3 & 4 & 5 & 6 & 7 & 8 & \text { Ld } & +\end{array}$

$\leftarrow 1 \mathrm{~Kb}$

$\leftarrow 375 \mathrm{bp}$ 


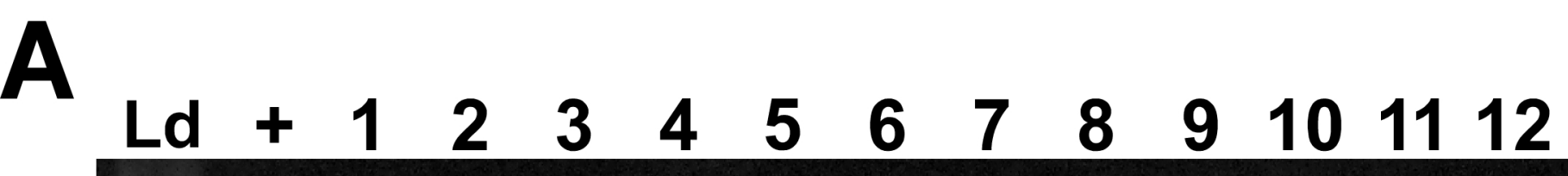

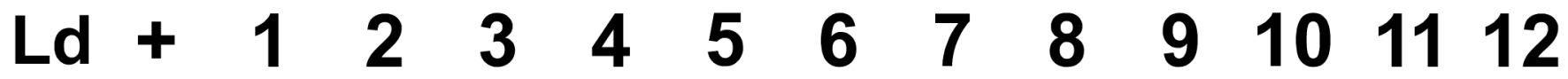

